\title{
Flavour development in aseptic cheese curd slurries prepared with single-strain starter bacteria in the presence and absence of adjuncts
}

\author{
C Wijesundera ${ }^{1}$, M Roberts ${ }^{1}$, GKY Limsowtin ${ }^{2}$ \\ ${ }^{\prime}$ CSIRO Division of Food Science and Technology, Melbourne Laboratory, \\ Graham Road, Highett, Victoria 3190; \\ ${ }^{2}$ Australian Starter Culture Research Centre Ltd, Private Bag 16, Werribee, Victoria 3030, Australia
}

\begin{abstract}
Summary - Eight strains of Lactococcus starter bacteria were tested under microbiologically controlled conditions for their ability to produce Cheddar cheese flavour. For this purpose, aseptic Cheddar cheese curds were prepared with each of the organisms, and the resulting curds slurried with sterile salt and water, and stored at $30^{\circ} \mathrm{C}$ for accelerated flavour development. Distinct though weak Cheddar cheese flavour was produced by the Lactococcus lactis subsp cremoris strain SK11, but not by strains ASCC457, ASCC50, ASCC109, ASCC660, ASCC 360, or the L lactis subsp lactis strain ASCC381, or the L lactis subsp lactis biovar diacetylactis strain ASCC250. Different starter strains produced different degrees of bitterness, with strains ASCC457, 109 and 660 producing the most bitter slurries. Strains SK11, ASCC50, ASCC360, and ASCC250 produced only slight bitterness in slurries ripened for 15 days. Free fatty acid concentrations in the slurries differed depending on the starter strain used, implying that different starter strains have different lipase activity. Cheese flavour development was slow in the slurries containing only starter bacteria. In contrast, slurries made with the strain SK11 in the presence of the adjuncts Lactobacillus helveticus ASCC395, Brevibacterium linens CSCC750 or Lactobacillus casei subsp casei NCDO151 underwent rapid flavour development, giving distinct and strong cheese (but not Cheddar) flavours for each adjunct. These differences in flavour, however, could not be explained in terms of differences in the non-sulphur volatile composition of the slurries determined by static headspace analysis.
\end{abstract}

Cheddar cheese / flavour development / starter bacteria / cheese curd slurry / headspace analysis / sensory analysis

Oral communication at the IDF Symposium 'Ripening and Quality of Cheeses', Besançon, France, February $26-28,1996$. 
Résumé - Développement de la saveur dans des caillés saumurés stériles préparés avec un levain à souche unique, avec ou sans ajouts de ferments. Huit souches de levain de type Lactococcus ont été placées dans des conditions stériles pour tester leur aptitude à produire la saveur caractéristique du Cheddar. À cet effet, on a préparé des caillés stériles de Cheddar avec chacune des souches, mélangés ensuite avec de la saumure stérile, puis stockés à $30^{\circ} \mathrm{C}$ pour accélérer le développement de la saveur. Seule la souche SK11, Lactococcus lactis subsp cremoris, a donné la saveur caractéristique du Cheddar, bien que faible, contrairement à d'autres souches du même type telles que ASCC457, ASCC50, ASCC109, ASCC660, ASCC360 ou la souche L lactis subsp lactis ASCC 381 , ainsi qu' une souche de $L$ lactis subsp lactis biovar diacetylactis ASCC250. Les différentes souches de levains ont induit plusieurs niveaux d'amertume. Les souches ASCC457, 107 et 660 ont produit les caillés saumurés les plus amers, tandis que les souches SK11, ASCC50, ASCC360 et ASCC 250 n'ont produit que très peu d'amertume dans des caillés saumurés maturés pendant 15 jours. Les différences de concentration en acides gras libres observées dans les caillés saumurés selon la souche de levain utilisée indiquaient des activités lipasiques différentes entre les souches. Le développement de la saveur Cheddar a été lent dans les caillés saumurés ne contenant que des levains lactiques. En revanche, les caillés saumurés contenant la souche SK11 additionnée de ferments tels que $L$ helveticus ASCC395, Brevibacterium linens CSCC750 ou L casei subsp casei NCDO151, ont développé rapidement des saveurs de fromages très prononcées, mais non caractéristiques du Cheddar, distincte pour chaque ferment additionné. Quoi qu'il en soit, ces différences de saveurs ne pourraient pas s'expliquer par les différences de composition en volatils non sulfureux déterminée par l'analyse statique des espaces de tête des caillés saumurés.

\section{fromage Cheddar / arôme / levain / caillé / analyse des espaces de tête / analyse sensorielle}

\section{INTRODUCTION}

Starter bacteria are used in the manufacture of essentially all cheeses. Their main function is to produce acid at the rate appropriate for the particular cheese being made. In the manufacture of Cheddar cheese, milk is inoculated with selected starter bacteria, primarily to produce lactic acid from lactose. The inoculated milk is coagulated through the action of rennet, the gel is cut, and the resulting curd is cooked, drained, cheddared, milled, salted, pressed and packaged for ripening. The properties of starter bacteria relevant to the manufacture of Cheddar cheese curd and the problems associated with the process, for example, susceptibility of starter strains to bacteriophage attack, have been investigated extensively (see Cogan and Hill, 1993). In contrast, relatively little is known about the contribution of starter bacteria to the production of Cheddar cheese flavour, despite the fact that cheese ripening has long been associated with bacterial activity.
Investigations by Reiter et al (1967) showed that starter bacteria are necessary for the formation of Cheddar cheese flavour. These workers, who made cheese under aseptic conditions with gluconic acid- $\delta$-lactone instead of starter, with starter only, and with starter plus non-starter lactic acid bacteria isolated from commercial cheeses, found that cheese made without starter was devoid of flavour. They also found that Cheddar flavour developed not only in cheese with starter plus non-starter microflora, but also in the cheese made with starter only. Different starters produced different intensities of flavour, suggesting that cheese flavour development could be manipulated by the appropriate selection of starter bacteria. However, selection of flavour-producing starter bacteria for the manufacture of Cheddar cheese is not a simple task. There are several reasons for this. Firstly, there are fundamental difficulties in standardising sensory evaluation of the contribution of starter bacteria to flavour development and in obtaining consistent definitions. Secondly, there are often 
other unknown factors to be taken into account, including milk composition, manufacturing and microbiological variables. The manufacture of all commercial and most experimental cheeses include an unknown and variable population of adventitious lactic acid bacteria which can contribute to flavour development (Crow et al, 1993). Some of these adventitious bacteria, lactobacilli in particular, have been associated with both desirable and undesirable effects on Cheddar flavour development (Peterson and Marshall, 1990). Finally, flavour development in Cheddar cheese is a rather slow process, requiring 6-12 months to determine the flavour characteristics produced by a starter strain.

Accelerated ripening via cheese curd slurries, first developed by Kristoffersen et al (1967), offers a rapid method for assessing starter bacteria for flavour potential. The original method involved homogenisation of fresh cheese curd in a solution of $\mathrm{NaCl}$, followed by incubation of the slurry at $30^{\circ} \mathrm{C}$. As a result of the elevated moisture content and temperature, strong flavours developed in the slurries within seven days, as compared to several months for regular cheese. Harper and Kristoffersen (1970) demonstrated that the slurry systems replicated the ripening processes of the natural cheeses by comparing the chemical composition of ripening slurries with that of the corresponding natural cheeses. Their work created an interest in using cheese curd slurries as model systems for investigating the cheese ripening process (Thakar and Upadhyay, 1992). However, subsequent attempts to use slurry systems for this purpose met with little success. This was due primarily to interference from contaminating microorganisms, originating in the milk or introduced during preparation of the slurries, which significantly alter the cheese ripening process with respect to proteolysis and flavour development. Roberts et al (1995) reported on a modified slurry technique, which makes it possible to ripen cheese curd slurries under aseptic conditions without interference from contaminating microorganisms. We now report on the application of this aseptic slurry technique for evaluating the flavour-generating potential of single-strain starter bacteria. Effects of the presence of selected non-starter bacteria on cheese flavour development are also described.

\section{MATERIALS AND METHODS}

\section{Cheese milk}

Cheese curds were made from commercial UHTtreated milk packed in 1-L cartons. The cheese curd slurries containing starter only were prepared from a batch of UHT milk manufactured in Australian mid-spring (October, 1994). The slurries containing adjuncts were made from a similar batch of milk made in October 1995. The cartons of milk were stored at $2{ }^{\circ} \mathrm{C}$ until used.

\section{Starter bacteria and adjuncts}

Freeze-dried starter bacteria and adjuncts were obtained from the collection of the Australian Starter Culture Research Centre (ASCRC). In this paper, the starter strains are referred to by their Australian Starter Culture Collection (ASCC) number. The bacteria were grown overnight in sterile, $10 \%$ reconstituted skim milk at $30^{\circ} \mathrm{C}$. The following starter strains were assessed: Lactococcus lactis subsp cremoris strains: ASCC457, ASCC50, ASCC109, ASCC660, ASCC 360 and SK11, the L lactis subsp lactis strain ASCC381, and the L lactis subsp lactis biovar diacetylactis strain ASCC250. The adjuncts tested were: Lactobacillus helveticus ASCC395, L casei subsp casei NCDO151, and Brevibacterium linens CSCC750.

\section{Preparation of cheese curd}

Cheese curds were prepared in the laboratory in $1-\mathrm{L}$ vats according to the normal Cheddar cheese manufacturing protocol as described by Roberts et al (1995). In order to prevent interference from contaminant microorganisms, the slurries were made from UHT-treated milk using sterile equip- 
ment under a laminar flow hood. Curds were prepared in duplicate for each starter or nonstarter organism tested.

\section{Preparation of cheese curd slurries}

The cheese curd was blended in stomacher bags with sterile water and $\mathrm{NaCl}$ to yield slurries containing $73 \%(\mathrm{w} / \mathrm{w})$ water and $3 \%$ salt in moisture. Approximately $9 \mathrm{~g}$ samples of the slurries were transferred into sterile headspace vials and flushed with nitrogen purified by passing through a Midisart 2000 filter (Sartorius, Gottingen, Germany), and sealed with Teflon-lined septa. All of the above operations were performed under a laminar flow hood to prevent contamination. The vials were incubated at $30^{\circ} \mathrm{C}$ for ripening.

\section{Microbiological analysis of cheese curd slurries}

Microbiological quality of the cheese curd slurries was assessed by enumerating coliform (Violet Red Bile Agar, Oxoid), Staphylococcus spp (Baird Parker medium, Oxoid), yeast and mould (Oxytetracycline-Glucose-Yeast Extract Agar, Oxoid), Bacillus spp (Plate Count Agar, Oxoid, by heating the samples at $80^{\circ} \mathrm{C}$ for $20 \mathrm{~min}$ prior to plating) and Lactobacillus spp (de Man, Rogosa and Sharp, Oxoid). Starter bacteria were enumerated using M17 (Merck).

\section{Chemical analysis of cheese curd slurries}

\section{Static headspace analysis by gas chromatography (GC)}

The slurries were ripened in sealed headspace vials for direct headspace analysis. A Perkin-Elmer Model HS 40 Headspace Autosampler coupled to a Perkin-Elmer Autosystem gas chromatograph, fitted with a flame ionisation detector (FID), was used for this purpose. A BP1 fused silica capillary column ( $25 \mathrm{~m}, 0.53 \mathrm{~mm}$ id, $5 \mu$ film; SGE, Melbourne, Australia) was used for chromatography under the following conditions: helium was used as the carrier gas at an initial $\left(40{ }^{\circ} \mathrm{C}\right)$ flow rate of $4.0 \mathrm{~mL} / \mathrm{min}$. The sample vial was equilibrated at $60^{\circ} \mathrm{C}$ for $30 \mathrm{~min}$ and a $10 \mathrm{~mL}$ sample of the headspace was automatically injected into the GC column, the front end of which was cryofocussed using a liquid nitrogen accessory. The oven temperature was maintained at the initial value of $40^{\circ} \mathrm{C}$ for $5 \mathrm{~min}$ and then increased at $5^{\circ} \mathrm{C} / \mathrm{min}$ to $100^{\circ} \mathrm{C}$, and at $10^{\circ} \mathrm{C} / \mathrm{min}$ to $180^{\circ} \mathrm{C}$. The headspace components were identified by comparison of their retention times with authentic standards and by gas chromatography/ mass spectrometric analysis. Peak areas were integrated using DAPA chromatographic software (DAPA Scientific, Perth, Australia).

\section{Gas chromatography/ mass spectroscopy (GC/MS)}

Gas chromatography/mass spectroscopy (GC/MS) analysis of the sample headspace was performed using a Finnigan 1020 mass spectrometer coupled to a Perkin-Elmer Sigma 3B GC, using a GC column identical to that used for headspace analysis by GC/FID. The sample vials were equilibrated for $30 \mathrm{~min}$ at $60^{\circ} \mathrm{C}$ and $5 \mathrm{~mL}$ samples of the headspace were manually injected to the GC using cryofocussing. The components were identified by comparison of their mass spectra to those in the computer library.

\section{Free fatty acid (FFA) analysis}

A $40 \mathrm{~g}$ sample of the slurry, containing 2-methyl butanoic acid as internal standard was subjected to high vacuum distillation for $4 \mathrm{~h}$, and the distillate was collected in a trap cooled in liquid nitrogen. The distillate was saturated with $\mathrm{NaCl}$, extracted with glass distilled diethyl ether $(5 \mathrm{~mL} 3)$ and dried with anhydrous sodium sulphate. Most of the ether was evaporated using a Raschid condenser, and the concentrate was analysed by GC/FID on a BP2 1 fused silica capillary column $(25 \mathrm{~m}, 0.53 \mathrm{~mm}$ id, $0.5 \mu$ film, SGE, Melbourne, Australia) using a temperature programme of $80-180^{\circ} \mathrm{C}$ at a ramp rate of 
$5^{\circ} \mathrm{C} / \mathrm{min}$. Helium was used as the carrier gas at a constant flow rate of $5.0 \mathrm{~mL} / \mathrm{min}$. Fatty acids were the dominant components of the extract and were identified by their retention times. The peak areas were integrated using DAPA chromatography software (DAPA Scientific, Perth, Australia).

\section{Taste panels}

The slurries were assessed for aroma and taste by a panel of three experienced cheese tasters. The panel was asked to score for cheesiness, Cheddariness, bitterness and any other detectable flavours using the scale: $\mathrm{s}=$ strong; $\mathrm{m}=$ moderate; and $w=$ weak.

\section{RESULTS AND DISCUSSION}

\section{Microbial changes}

Table I shows the changes in the populations of starter bacteria in aseptic Cheddar curd slurries made with starter only, or with starter plus adjuncts, during ripening up to 30 days. The populations of starter bacteria in the starter-only slurries were similar at a given stage of ripening, irrespective of the starter strain used; the average starter populations for eight different starter strains at various stages of ripening are shown in table I. This population of starter bacteria, which was $3.710^{8}$ colony forming units ( $\mathrm{cfu} / \mathrm{g}$ ) on the first day of ripening, declined to $2.110^{3} \mathrm{cfu} / \mathrm{g}$ after 10 days and $1.510^{2} \mathrm{efu} / \mathrm{g}$ after 20 days. The cheese curds made with SK11 as the starter plus each of the adjuncts, namely $L$ helveticus, $B$ linens or $L$ casei, had starter populations of $4.510^{7}, 4.210^{7}$, and $5.010^{7} \mathrm{cfu} / \mathrm{g}$ respectively on the first day of ripening. The starter bacteria in the last two slurries did not survive beyond 10 days of ripening. The slurry containing $L$ helveticus had a starter population of $1.010^{3} \mathrm{cfu} / \mathrm{g}$ at $\mathbf{1 0}$ days, but none at $\mathbf{2 0}$ days. In the starteronly slurries, as well as in the slurries containing adjuncts, the sharpest decline in the starter populations occurred between 1 and 10 days. No starter bacteria survived beyond 30 days of ripening in either type of slurry. The populations of the adjunct bacteria in the ripening cheese curd slurries are shown in table II. The populations of $L$ helveticus, $B$ linens and $L$ case $i$ on the first day of ripening were $7.810^{7}, 9.610^{6}$ and $1.410^{8}$ respectively. They declined to $6.110^{4}, 6.910^{4}$ and $8.010^{5}$ respectively after 10 days. The slur-

Table I. Starter counts in aseptic Cheddar curd slurries made with starter only or starter with adjuncts during ripening up to 30 days.

Dénombrement des levains dans des mélanges stériles de caillés saumurés de cheddar préparés à partir d'un levain seul ou à partir de levain additionné de ferments pendant une maturation de 30 jours.

\begin{tabular}{lllll} 
Culture & Day 1 & Day 10 & Day 20 & Day 30 \\
\hline Starter only & $3.710^{8}$ & $2.110^{3}$ & $1.510^{2}$ & ND \\
SK $11+$ L helveticus & $4.510^{7}$ & $1.010^{3}$ & ND & ND \\
SK11+ B linens & $4.210^{7}$ & ND & ND & ND \\
SK $11+$ L casei & $5.010^{7}$ & ND & ND & ND
\end{tabular}

The values for the starter only slurries are the averages for eight different strains. ND: $<10 \mathrm{cfu} / \mathrm{mL}$. Les valeurs pour les caillés saumurés à partir d'un levain seul sont des moyennes de huit souches différentes. 
Table II. Microbiological qualiy of cheese curd slurries made with starter only or with starter plus adjuncts during ripening up to 10 days.

Qualité microbiologique des caillés saumurés préparés à partir d'un levain seul ou d'un levain additionné de ferments après maturation de 10 jours.

Culture

Microbial count (cfiumL)

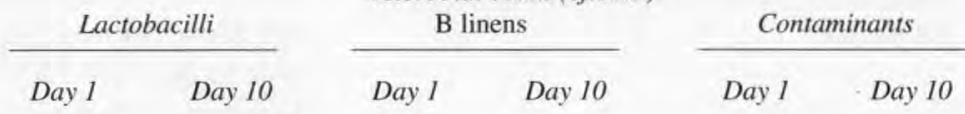

$\begin{array}{lllllll}\text { Starter only } & \text { ND } & \text { ND } & \text { ND } & \text { ND } & \text { ND } & \text { ND } \\ \text { SK } 11+\text { L helveticus } & 7.810^{7} & 6.110^{4} & \text { ND } & \text { ND } & \text { ND } & \text { ND } \\ \text { SK } 11+\text { B linens } & \text { ND } & \text { ND } & 9.610^{6} & 6.910^{4} & \text { ND } & \text { ND } \\ \text { SK } 11+\text { L casei } & 1.410^{8} & 8.010^{5} & \text { ND } & \text { ND } & \text { ND } & \text { ND }\end{array}$

Contaminants referred to in the table were tested for: coliforms, salmonellae, staphylococci, bacilli, yeasts and moulds. ND: $<10 \mathrm{cfu} / \mathrm{mL}$.

Les contaminations citées dans le tableau ont été testées pour les bactéries suivantes : coliformes, salmonelles, staphylocoques, bacilles, levures et moisissures.

ries made with starter bacteria only contained no lactobacilii at any stage of ripening. None of the slurries, whether they were made with starter only or with starter plus adjuncts, contained any microorganisms other than the bacteria being tested, thus preventing a possible influence on flavour development by contaminants.

\section{Flavour profiles}

\section{Slurries made with starter only}

Flavour characteristics of cheese slurries made with the eight different starter strains were assessed. For this purpose, aseptic cheese curd slurries prepared with each of the strains were ripened at $30^{\circ} \mathrm{C}$, and flavour development was monitored at regular intervals by sensory as well as headspace analysis. At 5 days, the slurries were generally bland, except for the taste of lactic acid. Table III shows the general flavour description of the slurries after ripening for 10 and 15 days. The slurries made with the starter strains SK11 and ASCC660 developed a weak cheese flavour at 15 days. The SK 11 slurry gave a weak but distinct Cheddar flavour at 15 days. Of the eight starter strains tested, SK11 was the only one to produce a typical Cheddar flavour in the slurries. The starter strains tested produced bitterness to different extents. The strains that produced strong bitterness were easily identified in 15 days. Strains ASCC457, ASCC109 and ASCC660 produced moderately bitter slurries in 10 days, whereas the strains SK11 and ASCC250 did not produce bitterness at this age. At 15 days, all of the starter-only slurries developed some bitterness, and the slurries made with strains ASCC457, ASCC109 and ASCC660 were more bitter than the others.

\section{Slurries made with starter and adjuncts}

Recent studies (McSweeny et al, 1993; Weimer et al, 1995) have shown that some non-starter lactic acid bacteria enhance flavour development in Cheddar cheese. As part of the present study, the newly developed aseptic cheese curd 
Table III. General flavour description of cheese curd slurries prepared with starter only and with starter and adjuncts during ripening at $30^{\circ} \mathrm{C}$.

Description générale des saveurs de caillés saumurés préparés à partir d'un levain seul ou d'un levain additionné de ferments pendant une maturation à $30^{\circ} \mathrm{C}$.

$\begin{array}{lll}\text { SK11 } & \text { Cultured milk } & \text { Cheddary (w), bitter (w) } \\ \text { ASCC457 } & \text { Bitter (m) } & \text { Bitter (s) } \\ \text { ASCC50 } & \text { Bitter (w) } & \text { Bitter (w) } \\ \text { ASCC109 } & \text { Bitter (m) } & \text { Bitter (s) } \\ \text { ASCC660 } & \text { Cheesy (w), bitter (m) } & \text { Cheesy (w), bitter (s) } \\ \text { ASCC360 } & \text { Sulphury (w), bitter (w) } & \text { Bitter (w) } \\ \text { ASCC381 } & \text { Buttery (w), bitter (m) } & \text { Buttery (w), bitter (m) } \\ \text { ASCC250 } & \text { Buttery (w) } & \text { Buttery (w), bitter (w) } \\ \text { SK11 + L helveticus } & \text { Cheesy (s), sweet (m) } & \text { Cheesy (s), sweet (m), bitter (w) } \\ \text { SK11 + B linens } & \text { Putrid (s) } & \text { Camembert (s), sulphury (w) } \\ \text { SK11 + L casei } & \text { Cheesy (s), buttery (s), sweet (m) } & \text { Cheesy (s), buttery (s), sweet (m) }\end{array}$

w: weak; m: moderate; s: strong.

$w$ : faible ; $m$ : moyen ; $s$ fort.

slurry system was used to determine the effect of the presence of adjunct bacteria on Cheddar flavour development. Table III shows the flavour description of three slurries made with SK11 starter in the presence of the adjuncts $L$ helveticus, $B$ linens or $L$ casei. The presence of the adjuncts dramatically changed the flavour characteristics of the slurries. After 10 days of ripening, the starter-only slurry tasted like cultured milk and had very little cheese flavour, whereas those containing the adjuncts had definite and strong flavours. The $L$ helveticus and $L$ casei slurries had sweet smells similar to that of Swiss cheese; the latter, however, was buttery while the former was slightly cheesy. At 10 days, the slurry containing $B$ linens had an intense putrid smell, but developed a typical Camembert flavour after 15 days. The $L$ helveticus slurry was slightly bitter at 15 days but retained its sweetness, while the $L$ case $i$ slurry remained buttery and sweet at 15 days. These results demonstrate that non-starter bacteria and other adjuncts can have a strong impact on the course of cheese flavour development. Flavour development in the starter-only slurry was slow, with only a weak cheese flavour after 15 days. However, the flavour which developed was distinctly Cheddar. Considering that the slurries were prepared under strictly aseptic conditions from UHT-treated milk, thus eliminating all contaminant bacteria, the development of typical Cheddar flavour in the starter only cheese shows that starter bacteria, at least in the case of SK11, are capable of producing characteristic Cheddar flavour in the absence of lactobacilli or other non-starter bacteria. However, flavour development under such conditions was rather slow. This observation is in agreement with the result of Reiter et al (1967), who found that Cheddar cheese made aseptically with starter only developed distinct Cheddar flavour, but did not possess the fullness of flavour of a mature Cheddar. More recently, McSweeney et al (1994), who prepared Cheddar cheese under controlled bacteriological conditions with and without adjunct lactobacilli, found that the starter only 
cheeses had lower flavour intensity than those containing added lactobacilli during ripening for 6 months. Neither type of cheese, however, developed strong Cheddar flavour. It appears, therefore, that a delicate balance between the starter and non-starter organisms is required for the development of typical and strong Cheddar flavour.

\section{Headspace composition}

Table IV shows the headspace composition (as determined by static headspace gas chromatography) of cheese curd slurries prepared with eight different single-strain starter bacteria, and ripened at $30^{\circ} \mathrm{C}$ for 3 weeks. All the compounds detected in the slurries, and listed in the table, are also normal constituents of mature Cheddar cheese. Ethanol and acetone (not shown) and diacetyl were common to all the slurries. Strains ASCC 457 and ASCC 250 produced significantly more diacetyl than the other strains tested. Culture ASCC250 was a strain of $L$ lactis subsp lactis biovar diacetylactis, which is known to metabolise citrate to produce diacetyl. However, to the best of our knowledge, the production of diacetyl by the strain ASCC 457 has not been reported.

Our results show that strain ASCC457 in fact generated more diacetyl than strain ASCC250. Figure 1 shows the variation of diacetyl concentration in slurries made with strains ASCC457 and ASCC 250 over a ripening period of 3 weeks. For all strains tested, the concentration of diacetyl decreased with the ripening time. Diacetyl is derived from the metabolism of citrate (Hugenholtz, 1993). The concentration of diacetyl in Cheddar cheese decreases gradually as the cheese matures, possibly due to chemical reaction with amino acids, to produce compounds which may contribute to Cheddar flavour (Lindsay, 1994). Hence, it is desirable that the

Table IV. Relative concentrations of selected volatile compounds in the headspace of cheese curd slurries made with single strain starter bacteria or starter (SK11) plus adjuncts, and ripened for three weeks at $30^{\circ} \mathrm{C}$. Concentration relative des composés volatils sélectionnés dans l'espace de tête des caillés saumurés préparés à partir d'un levain à souche unique ou à partir d'un levain (SK11) additionné de ferments et maturés à $30{ }^{\circ} \mathrm{C}$ pendant 3 semaines.

Culture

Headspace component

$$
\text { Diacetyl 3-Methyl butanal 2-Pentanone Acetoin 2,3-Butanediol }
$$

$\begin{array}{lrrrrr}\text { SK11 } & 28 & \text { ND } & \text { ND } & 209 & 1176 \\ \text { ASCC457 } & 878 & \text { ND } & \text { ND } & 64 & 2228 \\ \text { ASCC50 } & 42 & \text { ND } & \text { ND } & 31 & 176 \\ \text { ASCC109 } & 15 & \text { ND } & \text { ND } & 13 & 87 \\ \text { ASCC660 } & 52 & \text { ND } & \text { ND } & \text { ND } & \text { ND } \\ \text { ASCC360 } & 81 & \text { ND } & \text { ND } & 204 & 3640 \\ \text { ASCC381 } & 10 & \text { ND } & \text { ND } & 12 & 25 \\ \text { ASCC250 } & 525 & \text { ND } & \text { ND } & \text { ND } & 1321 \\ \text { SK 11+L helveticus } & 210 & 162 & 8 & 63 & 270 \\ \text { SK 11+ B linens } & 10 & \text { ND } & 2 & 123 & 551 \\ \text { SK 11+ L casei } & 166 & 966 & 12 & 14 & 316 \\ & & & & & \end{array}$

Values shown are average peak areas obtained by static headspace gas chromatography on triplicate samples (standard deviation 12-18\%); ND: not detected.

Les valeurs indiquées sont des moyennes des surfaces des pics obtenus par chromatographie gazeuse avec espace de tête statique sur des échantillons triples (déviation standard: $12-18 \%$ ). 
starter bacteria used to manufacture Cheddar cheese have the ability to produce diacetyl. Strains SK11 and ASCC 360 produced relatively large concentrations of acetoin, but relatively low levels of diacetyl (table IV). Both diacetyl and acetoin are considered to be derived from the unstable common precursor, $\alpha$-acetolactic acid, the former by chemical decarboxylation, the latter by enzymic decarboxylation via $\alpha$-acetolactate decarboxylase (Hugenholtz, 1993). It appears, therefore, that the strains SK11 and ASCC 360 contain an efficient $\alpha$-acetolactate decarboxylase systems compared to the strains ASCC 457 or ASCC250, which produced relatively high concentrations of diacetyl but only low levels of acetoin. Butanone was absent from the starter-only slurries throughout the ripening period investigated. Butanone is derived from 2,3-butanediol (Scarpellino and Kosikowski,

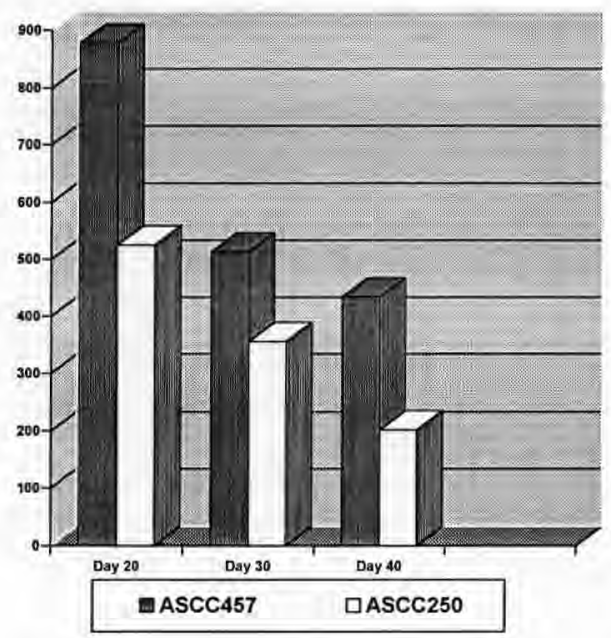

Fig 1. Changes in the concentration of diacetyl during ripening in cheese curd slurries made with starter strains ASCC457 or ASCC250. The values shown are relative peak areas for diacetyl in static headspace analysis by GC/FID.

Changements de concentration en diacétyle au cours de la maturation des caillés saumurés préparés à partir des souches de levain ASCC457 ou ASCC250. Les valeurs indiquées sont les surfaces relatives des pics pour le diacétyle dans l'analyse de l'espace de tête statique $G C / F I D$.
1962), and according to Keen et al (1974), this conversion can only take place when non-starter organisms are present.

Microbiological examination of our slurries did not show contamination at any stage of ripening; thus our results are in agreement with the conclusion of Keen et al (1974). Butanone occurs in commercial Cheddar cheese at various concentrations, but is not generally thought to contribute to Cheddar flavour. 2,3-Butanediol was present in the slurries at various concentrations, except for that prepared with strain ASCC660. Indeed, it was the most abundant component in headspace of slurries made with strains ASCC 457, ASCC 360 , SK 11 or ASCC 250. Given its extreme solubility in water, butanediol would have been present in even higher relative concentrations in the aqueous phase of the slurry. With one exception, the slurries containing a high concentration of butanediol also contained a high level of acetoin from which it is probably derived. The exception was strain ASCC 250 which produced high concentrations of both butanediol and diacetyl, but did not contain acetoin

Although the slurries containing different adjuncts had aromas markedly different from each other and from the slurry made using starter only, their headspace compositions (table IV) were not qualitatively very different from those made with starter only. The major difference between the compositions was the presence of 3 methyl butanal and 2-pentanone in the slurries containing $L$ helveticus or $L$ casei. The former has a malty flavour and this may, at least part, account for the sweet flavour in these two slurries. However, the distinctive flavour differences between the slurries containing the adjuncts can not be attributed to these additional components. It appears that the volatile components responsible for the characteristic aromas of the adjunctcontaining slurries occur in concentrations lower than those which could be detected by the methods used in the present study. More sensitive analytical techniques are required for the identification of the flavour compounds responsible 
for the different aromas produced in the adjunctcontaining slurries.

Table $\mathrm{V}$ shows the relative concentrations of free fatty acids (FFA) in aseptic cheese curd slurries made with different starter strains. The method of vacuum distillation/GLC used for this determination permitted analysis of acids up to dodecanoic acid ( $\mathrm{C} 12)$ in the slurries. Also, the distillation step favours shorter chain acids at the expense of the longer chain ones, and hence the absolute concentrations of acids with chain lengths longer than $\mathrm{C} 8$ may be underestimated. The results show that the starter strains tested differed from each other in their ability to form FFA. Strains SK11, ASCC660, and ASCC250 produced more $\mathrm{C} 10$ and $\mathrm{C} 12$ acids than did the other strains. Since lipolysis is considered to be the principal contributor to FFA of chain length C4 or greater (Aston and Dulley, 1982), it can be concluded that strains SK11, ASCC660 and ASCC250 are more lipolytic than the other strains. In general, however, the overall concentrations of FFA in the slurries were of the same order of magnitude as the values reported for commercial Cheddar cheese (Barlow et al, 1989). Reiter et al (1969) reported that although starter bacteria are lipolytic, their contribution to the release of FFA in cheese is less important than that of the indigenous milk lipase. In the present study, the UHT milk used for cheesemaking contained only low levels of acetic acid $(0.2 \mu \mathrm{g} / \mathrm{g})$ and butanoic acid $(0.6 \mu \mathrm{g} / \mathrm{g})$, and was free of higher FFA. We did not, however, measure the FFA levels in UHT milk stored for the same length of time as the cheese curd slurries, and it was possible that the FFA in the stored slurries were formed partly by the action of the natural lipase of milk. However, the FFA in the slurries could not have been formed solely by the milk lipase, because if this was the case, the FFA profiles in different slurries would have been the same irrespective of the starter strain used. The fact that different FFA profiles were obtained with different starter strains shows that, firstly, starter bacteria contribute to lipolysis in Cheddar cheese, and secondly, different starter strains have different lipolytic activity. Free fatty acid profiles in the slurries containing adjuncts were not investigated in the present study.

Table V. Concentration of free fatty acids in 40-days old cheese curd slurries $(\mu \mathrm{g} / \mathrm{g})$ as determined as gas chromatography on a BP21 fused silica capillary column using 2-methylpentanoic acid as internal standard. Concentration en acides gras libres $(\mu \mathrm{g} / \mathrm{g})$ des caillés saumurés âgés de 40 jours déterminée par chromatographie gazeuse sur colonne capillaire BP21 en silice fondue utilisant l'acide 2-méthylpentanö̈que comme standard interne.

Strain

Free fatty acid concentration $(\mu \mathrm{g} / \mathrm{g})$

$\begin{array}{lllllll}\text { C4 } & \text { C5 } & & \text { C6 } & \text { C8 } & \text { ClO } & \text { C12 }\end{array}$

$\begin{array}{lcccccc}\text { SK11 } & 1.7 & \text { ND } & 1.7 & 1.2 & 13.7 & 17.5 \\ 457 & 2.0 & 0.05 & 2.5 & 3.0 & 4.0 & 2.0 \\ 50 & 2.0 & \text { ND } & 4.0 & 2.0 & 3.0 & 2.2 \\ 109 & 12.5 & 0.5 & 4.5 & 1.0 & 1.7 & 0.7 \\ 660 & 0.7 & \text { ND } & 6.2 & 5.0 & 28.2 & 34.5 \\ 360 & 5.5 & 0.17 & 5.2 & 2.2 & 4.7 & 5.2 \\ 381 & 2.0 & \text { ND } & 4.2 & 6.2 & 6.2 & 0.2 \\ 250 & 2.5 & 0.07 & 3.7 & 5.2 & 6.5 & 21.0\end{array}$

ND: not detected. 


\section{CONCLUSION}

The cheese curd slurries investigated in this study were prepared and ripened under totally aseptic conditions - the only bacteria present in the slurries were the starter bacteria or the adjuncts under investigation. Under these controlled conditions, cheese flavour development in slurries containing only starter bacteria was retarded compared to slurries containing added non-starter bacteria, showing that non-starter bacteria have an important role in cheese flavour development. The flavour characteristics of the cheese curd slurries made with the three different adjuncts were distinctly different from each other. This suggests a possibility of obtaining controlled and directed flavour development in commercial cheeses by judicious use of nonstarter bacteria or adjuncts. Future experiments will include pilot-scale manufacture of cheese containing added non-starter bacteria.

\section{ACKNOWLEDGMENT}

We thank the Dairy Research and Development Corporation (DRDC) Australia for partial financial support.

\section{REFERENCES}

Aston JW, Dulley JR (1982) Cheddar cheese flavour. Austr J Dairy Technol 1, 59-63

Barlow I, Lloyd GT, Ramshaw EH, Miller AJ, McCabe GP, McCabe L (1989) Correlations and changes in flavour and chemical parameters of Cheddar cheeses during maturation. Austr J Dairy Technol 1, 7-18; raw data, Dairy Res Rep no 43

Crow VL, Coolbear T, Holland R, Pritchard GG, Martley FG (1993) Starters as finishers: starter properties relevant to cheese ripening. Int Dairy $J 3$, 423-460

Cogan TM, Hill C (1993) Cheese starter cultures. In: Cheese Chemistry, Physics and Microbiology, vol 1 (Fox PF, ed) Chapman and Hall, London

Harper WJ, Kristoffersen T (1970) Biochemical aspects of flavor development in Cheddar cheese slurries. I Agric Food Chem 18, 563-566
Hugenholtz J (1993) Citrate metabolism in lactic acid bacteria. FEMS Microbiol Rev 12, 165-178

Keen AR, Walker NJ, Pederby MF (1974) The formation of 2-butanone and 2-butanol in Cheddar cheese. J Dairy Res 41, 249-257

Kristoffersen T, Mikolajaik EM, Gould IA (1967) Cheddar cheese flavour. IV. Directed and accelerated ripening process, J Dairy Sci 50, 292-297

Lindsay RC (1994) Mechanisms for production of cheese flavour compounds. Annu Rep, Wisconsin Dairy Res Center, 74-75

McSweeney PLH, Fox PF, Lucey JA, Jordan KN, Cogan TM (1993) Contribution of indigenous microflora to the maturation of Cheddar cheese. Int Dairy J 3, 613-634

McSweeney PLH, Walsh EM, Fox PF, Cogan TM, Drinan FD, Castelo-Gonzalez M (1994) A procedure for the manufacture of Cheddar cheese under controlled bacteriological conditions and the effect of adjunct lactobacilli on cheese quality. Irish $J$ Agric Food Res 33, 183-192

Peterson SD, Marshall RT (1990) Nonstarter lactobacilli in Cheddar cheese. J Dairy Sci 73, 1395 1410

Reiter B, Fryer TF, Pickering A, Chapman HR, Lawrence RC, Sharpe ME (1967) The effects of the microbial flora on the flavour and free fatty acid composition of Cheddar cheese. J Dairy Res 34 , 257-272

Reiter B, Sorokin Y, Pickering A, Hall AJ (1969) Hydrolysis of fat and protein in small cheeses made under aseptic conditions. I Dairy Res 36, 65-76

Roberts M, Wijesundera C, Bruinenberg PG, Limsowtin GKY (1995) Development of an aseptic cheese curd slurry system for cheese ripening studies. Aust J Dairy Technol 50, 66-69

Scarpellino R, Kosikowski FV (1962) Evolution of volatile compounds in ripening raw and pasteurised milk Cheddar cheese observed by gas chromatography. J Dairy Sci 45, 343-348

Thakar PN, Upadhyay KG (1992) Cheese curd slurry - a review. Cult Dairy Prod J 27, 9-12

Weimer B, Brennand C, Broadbent J, Jaequ J, Johnson M, Milani F, Mistry B, Reineccius G, Steel J, Strickland M (1995) Chemical and sensory attributes of $50 \%$ reduced-fat Cheddar made with various adjunct bacteria. Int Lactic Acid Bacteria Conf, Palmerston North, New Zealand (abstr) 